\title{
Prevalence of Salmonella spp. in Packed and Unpacked Red Meat and Chicken in South of Tehran
}

\author{
Mohammad Mehdi Soltan Dallal ${ }^{1,2,}$; Mohammad kazem Sharifi Yazdi ${ }^{3,4}$; Nima Mirzaei ${ }^{5}$; \\ Enayat Kalantar ${ }^{1,6}$
}

${ }^{1}$ Food Microbiology Research Center, Tehran University of Medical Sciences, Tehran, IR Iran

${ }_{2}^{2}$ Division of Microbiology, Department of Pathobiology, School of Public Health, Tehran University of Medical Sciences, Tehran, IR Iran

${ }^{3}$ Zoonosis Research Centre, Tehran University of Medical Sciences, Tehran, IR Iran

${ }_{5}^{4}$ Department of Medical Laboratory Sciences, School of Paramedicine, Tehran University of Medical Sciences, Tehran, IR Iran

5 Department of Medical Laboratory Sciences, School of Paramedicine, Tehran University of Medical

6 Department of Microbiology, Science and Research Branch, Islamic Azad University, Tehran, IR Iran
${ }_{\text {Department }}$ of Microbiology, Faculty of Medicine, Alborz University of Medical Sciences, Karaj, IR Iran

${ }^{*}$ Corresponding author: Mohammad Mehdi Soltan Dallal, Food Microbiology Research Center, Tehran University of Medical Sciences, Tehran, IR Iran. Tel: + 98-2166462268, Fax: + 982166462267, E-mail: soltanirad34@yahoo.com

Received: November 26, 2012; Revised: May 5, 2013; Accepted: June 25, 2013

\begin{abstract}
Background: Despite of the advances in infectious diseases prevention and food technology, food-borne diseases are considered major problems in developed and developing countries. Meat plays a key role in transferring zoonotic diseases to human.

Objectives:This study was conducted in south of Tehran,Iran, to investigate the prevalence rate of Salmonella spp. in packed and unpacked red meat and chicken.

Materials and Methods: A total of 379 packed and unpacked samples including 189 red meat and 190 chicken samples were collected randomly. From each sample, $25 \mathrm{~g}$ was separated and treated with $225 \mathrm{~mL}$ of buffered peptone water, homogenized and incubated at $37^{\circ} \mathrm{C}$ for 24 hours. Samples were enriched using Rappaport-Vassiliadis broth and then streaked onto Hektoen enteric agar.

Results: Totally, 86 out of 190 chicken and 38 out of 189 red meat samples were contaminated with Salmonella spp. The most isolated serotypes were Salmonella thompson (67.7\%), S. heaardt (6.5\%), S. enteritidis (4.8\%), and S. veyle(4\%), respectively. In general, the rate of chicken contamination was higher than meat, as $43.3 \%$ of packed and $46 \%$ of unpacked chicken samples were contaminated.

Conclusions: These results confirmed the pervious findings, stating that proper packaging of meat products can effectively decreases the rate of microbial contaminations.
\end{abstract}

Keywords:SopD Protein, Salmonella; Meat Products; Chicken; Food Quality

\section{Background}

Foodborne diseases are one of the serious problems in developed and developing countries. Every year, more than 100 million people are afflicted by foodborne and waterborne diseases in the world, especially people with immune system deficiency and malnutrition $(1,2)$. Different species of Salmonella, Listeria and Yersinia are related to the diseases, which can be transmitted through consuming contaminated fish, dairy products, vegetables and meat $(3,4)$.

Epidemiological studies have shown that foods of animal origin are among the most important sources of foodborne diseases $(5,6)$. Food products are usually contaminated with pathogens during the production, processing, distributing and retailing in the market (7). Different studies showed that the frequencies of beef contaminations with human pathogens such as Salmonella were not the same (8-10).

Salmonellosis is the major cause of foodborne infec- tions and the second-most common foodborne illness after Campylobacter infection (11). Salmonella infection in human is often resulted from ingestion of contaminated foods such as beef, pork, egg, milk, seafood, and fresh products (11-15). Pathogens can survive in the food products, especially in meat, until distributed in the markets $(16,17)$. One of the best methods to prevent food products contamination is packaging. In the industrialized countries, food products are mostly distributed in the form of packages. In Iran, some food products such as chicken and beef are traditionally distributed unpackaged. Meat products are one of the most consumed foods; hence, they have a key role in transmission of Salmonella to humans. There are annually thousands of reported cases of foodborne diseases related to Salmonella in Iran. Many of Salmonella specie isolated from meat products are multidrug resistant strains, which can cause serious problems $(18,19)$.

The current study has several effects on health. One of the major outcomes of this study is that packaging decreases the rate of meat and chicken contaminations, which is recommended.

Copyright (C) 2014,Ahvaz Jundishapur University of Medical Sciences; Published by Kowsar Corp. This is an open-access article distributed under the terms of the Creative Commons Attribution License, which permits unrestricted use, distribution, and reproduction in any medium, provided the original work is properly cited. 


\section{Objectives}

The aim of this study was to compare the contamination rate of Salmonella in packaged and unpackaged chicken and beef products as well as the effect of packaging on contamination prevention.

\section{Materials and Methods}

\subsection{Sample Collection}

A total of 379 samples, including 189 beef and 190 chicken samples were collected from different stores in Tehran. All samples were kept at $4^{\circ} \mathrm{C}$ before and during transferring to the laboratory.

\subsection{Isolation, Identification and Serotyping of Sal- monella}

Identification of Salmonella was performed according to ISO-6575 (20). From each sample, $25 \mathrm{~g}$ was placed in a sterile stomacher bag and $225 \mathrm{~mL}$ buffered peptone water, pH 7.0 (Merck, Germany) was added to it. Samples were then homogenized using a stomacher for at least 2 minutes, followed by incubation at $37^{\circ} \mathrm{C}$ for 24 hours. Afterwards, $0.1 \mathrm{~mL}$ of pre-enriched broth was transferred into $10 \mathrm{~mL}$ of Rappaport-Vassiliadis medium (Oxoid, UK) and incubated at $42^{\circ} \mathrm{C}$ for 24 hours.

The enriched samples were then plated onto Hektoen enteric agar (Sigma, USA) and incubated at $37^{\circ} \mathrm{C}$ for 24 hours. Colonies on Hektoen enteric agar were then identified using biochemical tests such as oxidase reaction, acid production from manitol, ONPG test, $\mathrm{H}_{2} \mathrm{~S}$ and indole production, and urease and lysine decarboxylase activity. For final identification and verification, isolated strains were cultured on differential media such as Simmon's citrate agar, urea broth, lysine iron agar, methyl red and sulfide indole motility (SIM), and then incubated at $37^{\circ} \mathrm{C}$ for 24 hours.

Serotyping was performed according to KaufmannWhite scheme using O antisera (Difco, USA) (21) and flagellar antigens were detected by a technique of utilizing microtitre plates (22). Putative Salmonella isolates were transferred to Razi Vaccine and Serum Research Institute for serotyping.

\subsection{Statistical Analysis}

Statistical analysis was performed using SPSS software version 19. The P values $<0.05$ were considered statistically significant.

\section{Results}

Out of 379 samples, 134 (32.7\%) were contaminated (Table 1) and 13 serotypes were identified (Table 2 ). The most isolated serotypes were S. thompson (67.7\%), S. haardt (6.5\%) and S. veyle (4.8\%), respectively (Table 2$)$. Of S. thompson serotype, 65 were isolated from beef and 19 from chicken.
Rates of isolated Salmonella spp. from unpackaged and packaged beef and chicken samples were $22.3 \%, 16.4 \%$, $46 \%, 43.3 \%$, respectively (Table 3 ). Isolation rate of Salmonella spp. from unpackaged chicken was $46 \%$, which was significantly higher than unpackaged beef with the rate of $22.3 \%$. The statistical analysis difference rate among different sources of chicken and beef Salmonella spp. isolates was $\mathrm{P}<0.05$. Serotypes were more variable in unpackaged samples (Table 4). The contamination rates of samples were not related to the collection region.

The most isolated serotype from the packaged beef and chicken was S. thomson with the rate of $4.8 \%$ and $28.6 \%$, respectively. S. enteritidis (16.7\%), S. haardt (12.5\%) and S. virginia (33.3\%) were detected in the packaged chicken samples (Table 5) and S. anatum and S. meleagridis (100\%) were detected only in the packaged samples, S. paratyphi $\mathrm{C}$ and S. kentucky $(100 \%)$ were detected only in the unpackaged samples (Table 4).

The most isolated serotypes in the unpackaged beef and chicken samples were S. thampson, S. paratyphi, S. haard, S. enteritidis, and $S$. virigina was detected in the unpackaged chicken samples. S. voyle (60\%), Salmonella group II (100\%) and S. kentucky (100\%) were isolated from the unpackaged beef samples. Salmonella group F, S. meleagrides were not isolated from the unpackaged samples (Table 5).

Table 1. Prevalence of Salmonella spp. in Beef and Chicken Samples ${ }^{\text {a }}$

\begin{tabular}{llll}
\hline Type of Sample & Positives & Negative & Total \\
\hline Chicken & $86(45)$ & $104(55)$ & $190(100)$ \\
Beef & $38(20.2)$ & $151(79.8)$ & $189(100)$ \\
Total & $124(32.7)$ & $255(67.3)$ & $379(100)$ \\
\hline
\end{tabular}

${ }^{\mathrm{a}}$ Data are presented as No.(\%).

Table 2. Distribution of Salmonella Serotypes in Beef and Chicken Samples ${ }^{\text {a }}$

\begin{tabular}{llll}
\hline Serotype & \multicolumn{3}{c}{ Type of Samples } \\
\cline { 2 - 4 } & Beef & Chicken & Total \\
\hline S. thompson & $19(50)$ & $65(75.6)$ & $84(67.7)$ \\
S. paratyphi C & $1(2.6)$ & $2(2.3)$ & $3(2.4)$ \\
\hline S. anatum & $1(2.6)$ & $0(0)$ & $1(0.8)$ \\
\hline S. veyle & $5(13.2)$ & $0(0)$ & $5(4)$ \\
\hline S. enteritidis & $1(2.6)$ & $5(5.8)$ & $6(4.8)$ \\
\hline S. haardt & $2(5.3)$ & $6(7)$ & $8(6.5)$ \\
\hline S. virginia & $0(0)$ & $3(3.5)$ & $3(2.4)$ \\
\hline Salmonella group II & $1(2.6)$ & $0(0)$ & $1(0.8)$ \\
\hline S. meleagridis & $2(5.3)$ & $0(0)$ & $2(1.6)$ \\
\hline S. typhimurium & $2(5.3)$ & $1(1.2)$ & $3(2.4)$ \\
\hline S. untypable & $2(5.3)$ & $4(4.7)$ & $6(4.8)$ \\
\hline S. kentucky & $1(2.6)$ & $0(0)$ & $1(0.8)$ \\
\hline Salmonella group F & $1(2.6)$ & $0(0)$ & $1(0.8)$ \\
\hline Total & $38(100)$ & $86(100)$ & $124(100)$ \\
\hline a Data are presented as No. (\%). & &
\end{tabular}


Table 3. Distribution of Salmonella Serotypes in the Packaged and Unpackaged Chicken and Beef Samples a,b

\begin{tabular}{llll}
\hline Type of Sample & Positives & Negative & Total \\
\hline Packaged beef & $11(16.4)$ & $56(83.6)$ & $67(100)$ \\
Unpackaged beef & $27(22.3)$ & $93(77.7)$ & $122(100)$ \\
Packaged chicken & $29(43.3)$ & $38(56.7)$ & $67(100)$ \\
Unpackaged chicken & $57(46)$ & $66(45)$ & $123(100)$ \\
Total & $124(32.7)$ & $223(58.8)$ & $379(100)$ \\
\hline
\end{tabular}

a Data are presented as No.(\%).

b $\mathrm{x} 2=6.91$, d. f. $=3, \mathrm{P}=0.75$.

Table 4. Distribution of Salmonella Serotypes in the Packaged and Unpackaged Samples ${ }^{a}$

\begin{tabular}{llll}
\hline Serotype & \multicolumn{3}{l}{ Type of Sample } \\
\cline { 2 - 4 } & Packaged & unpackaged & Total \\
\hline S. thompson & $28(70)$ & $56(66.7)$ & $84(67.7)$ \\
S. paratyphi C & $0(0)$ & $3(3.6)$ & $3(2.4)$ \\
S. anatum & $1(2.6)$ & $0(0)$ & $1(0.8)$ \\
S. veyle & $2(5)$ & $3(3.6)$ & $5(4)$ \\
S. enteritidis & $1(2.6)$ & $5(5.8)$ & $6(4.8)$ \\
S. haardt & $1(2.6)$ & $7(8.3)$ & $8(6.5)$ \\
S. virginia & $1(2.6)$ & $2(2.4)$ & $3(2.4)$ \\
Salmonella group II & $0(0)$ & $1(1.2)$ & $1(0.8)$ \\
S. meleagridis & $2(5)$ & $0(0)$ & $2(1.6)$ \\
S. typhimurium & $0(0)$ & $3(3.6)$ & $3(2.4)$ \\
S. untypable & $3(7.5)$ & $3(3.6)$ & $6(4.8)$ \\
\hline S. kentucky & $0(0)$ & $1(1.2)$ & $1(0.8)$ \\
Salmonella group F & $1(2.6)$ & $0(0)$ & $1(0.8)$ \\
\hline Total & $40(100)$ & $84(100)$ & $124(100)$ \\
\hline Data
\end{tabular}

${ }^{a}$ Data are presented as No.(\%).

\section{Discussion}

Salmonellosis is one of the most important foodborne diseases (23). High prevalence of Salmonella species in chicken and beef samples obtained in this study was similar to the previous studies (11, 24-26). Salmonella spp. infections are usually caused by handling or consuming contaminated food products (27-30). In this study, the prevalence of Salmonella spp. in chicken meat samples was higher than beef samples. After death, the level of $\mathrm{pH}$ is reduced in animal tissues, leading to the decrease of bacterial growth in beef samples. A few previous studies have shown that bacteria normally grow more slowly in meat products with low $\mathrm{pH}$ levels (31).
Table 5. Distribution of Salmonella Strains in the Packaged and Unpackaged Beef and Chicken Samples ${ }^{\text {a }}$

\begin{tabular}{|c|c|c|c|c|}
\hline \multirow[t]{2}{*}{ Serotype } & \multicolumn{2}{|c|}{ Chicken } & \multicolumn{2}{|r|}{ Beef } \\
\hline & Packaged & Unpackaged & Packaged & Unpackaged \\
\hline $\begin{array}{l}\text { S. thompson } \\
(\mathbf{n}=\mathbf{8 4})\end{array}$ & $24(28.6)$ & $41(48.8)$ & $4(4.8)$ & $15(17.9)$ \\
\hline $\begin{array}{l}\text { S. paratyphi } \\
C(\mathbf{n}=3)\end{array}$ & $0(0)$ & $2(66.7)$ & $0(0)$ & $1(33.3)$ \\
\hline $\begin{array}{l}\text { S. anatum } \\
(\mathbf{n}=\mathbf{1})\end{array}$ & $0(0)$ & $0(0)$ & $0(0)$ & $1(100)$ \\
\hline $\begin{array}{l}\text { S. veyle (n } \\
=5)\end{array}$ & $0(0)$ & $0(0)$ & $2(40)$ & $3(60)$ \\
\hline $\begin{array}{l}\text { S. enteritidis } \\
(\mathbf{n}=6)\end{array}$ & $1(16.7)$ & $4(66.7)$ & $0(0)$ & $1(16.7)$ \\
\hline $\begin{array}{l}\text { S. haardt (n } \\
=8)\end{array}$ & $1(12.5)$ & $5(62.5)$ & $0(0)$ & $2(25)$ \\
\hline $\begin{array}{l}\text { S. virginia (n } \\
=3 \text { ) }\end{array}$ & $1(33.3)$ & $2(66.7)$ & $0(0)$ & $0(0)$ \\
\hline $\begin{array}{l}\text { Salmonella } \\
\text { group II (n } \\
=1)\end{array}$ & $0(0)$ & $0(0)$ & $0(0)$ & $1(100)$ \\
\hline $\begin{array}{l}\text { S. meleagri- } \\
\text { dis }(n=2)\end{array}$ & $0(0)$ & $0(0)$ & $2(100)$ & $0(0)$ \\
\hline $\begin{array}{l}\text { S. typhimuri- } \\
\text { um }(\mathrm{n}=3)\end{array}$ & $0(0)$ & $1(33.3)$ & $0(0)$ & $2(66.7)$ \\
\hline $\begin{array}{l}\text { S. untypable } \\
(\mathrm{n}=6)\end{array}$ & $2(33.3)$ & $2(33.3)$ & $1(16.7)$ & $1(16.7)$ \\
\hline $\begin{array}{l}\text { S. kentucky } \\
(\mathrm{n}=1)\end{array}$ & $0(0)$ & $0(0)$ & $0(0)$ & $1(100)$ \\
\hline $\begin{array}{l}\text { Salmonella } \\
\text { group } \mathrm{F}(\mathrm{n} \\
=1)\end{array}$ & $0(0)$ & $0(0)$ & $1(100)$ & $0(0)$ \\
\hline
\end{tabular}

Serotypes such as S. thampson, S. typhimurium, S. enteridis, S. infantis, S. paratyphi B were isolated from chicken and beef samples in the previous studies (32). The most isolated serotypes in this study were S. thompson, S. paratyphi C, S. enteridis, S. infantis, S. haardt, and S. typhimurium, which was similar to other finding (26). Isolation of invasive serotypes such as $S$. typhimurium indicates the public health significance and may pose health hazards, especially if chicken is consumed undercooked or crosscontamination occurs in kitchen during the meal preparation. The dominated serotype was S. thampson, which might be due to cross-contamination during product handling and distribution. Infection with S. thampson causes diarrhea, nausea and vomiting in humans as well as several diseases in immune-compromised individuals (33).

Contamination rates of the unpackaged samples with different serotypes of Salmonella spp. were higher com- 
pared with the packaged ones in both chicken and beef samples. Moreover, Salmonella serotypes were detected significantly higher in the unpackaged chicken compared with unpackaged beef; this might be due to specific physiological features of the beef tissue. We detected Salmonella serotypes more frequently during June, July, September and August, the hottest months of the year in Tehran. Previous studies also showed higher levels of Salmonella serotypes detection during summer (34).

\section{Acknowledgements}

We would like to thank the research team of Food Microbiology Research Center (FMRC) for their sincere help in performing technical parts of the project and Razi Institute for serotyping of Salmonella.

\section{Authors' Contributions}

None declared.

\section{Financial Disclosure}

Authors did not have any financial interests related to the content of this manuscript.

\section{Funding/Support}

There is no Funding/Support.

\section{References}

1. Egli T, Koster W, Meile L. Pathogenic microbes in water and food: changes and challenges. FEMS Microbiol Rev. 2002;26(2):111-2.

2. Todd EC. Epidemiology of foodborne diseases: a worldwide review. World Health Stat Q. 1997;50(1-2):30-50.

3. Tacket CO, Narain JP, Sattin R, Lofgren JP, Konigsberg C, Jr., Rendtorff RC, et al. A multistate outbreak of infections caused by Yersinia enterocolitica transmitted by pasteurized milk. JAMA. 1984;251(4):483-6.

4. McLauchlin J, Hall SM, Velani SK, Gilbert RJ. Human listeriosis and pate: a possible association. BMJ.1991;303(6805):773-5.

5. Tauxe RV. Emerging foodborne diseases: an evolving public health challenge. Emerg Infect Dis. 1997;3(4):425-34.

6. Petersen KE, James WO. Agents, vehicles, and causal inference in bacterial foodborne disease outbreaks: 82 reports (1986-1995). J Am Vet Med Assoc. 1998;212(12):1874-81.

7. Ono K, Yamamoto K. Contamination of meat with Campylobacter jejuni in Saitama, Japan. Int J Food Microbiol. 1999;47(3):2119.

8. Jorgensen F, Bailey R, Williams S, Henderson P, Wareing DR, Bolton FJ, et al. Prevalence and numbers of Salmonella and Campylobacter spp. on raw, whole chickens in relation to sampling methods. Int J Food Microbiol. 2002;76(1-2):151-64.

9. Pui CF, Wong WC, Chai LC, Tunung R, Jeyaletchumi P, Hidayah N, et al. Salmonella: A foodborne pathogen. Int Food Res J. 2011;18(2).

10. Zaidi MB, Calva JJ, Estrada-Garcia MT, Leon V, Vazquez G, Figueroa $\mathrm{G}$, et al. Integrated food chain surveillance system for Salmonella spp. in Mexico. Emerg Infect Dis. 2008;14(3):429-35.

11. Meldrum RJ, Wilson IG. Salmonella and Campylobacter in United Kingdom retail raw chicken in 2005. J Food Prot. 2007;70(8):19379.

12. L. Plym F, Wierup M. Salmonella contamination: a significant challenge to the global marketing of animal food products. Rev Sci Tech. 2006;25(2):541-54.

13. Centers for Disease, Control, Prevention.. Preliminary FoodNet data on the incidence of infection with pathogens transmitted commonly through food-10 States, United States, 2005. MMWR Morb Mortal Wkly Rep. 2006;55(14):392-5.

14. Dalton CB, Gregory J, Kirk MD, Stafford RJ, Givney R, Kraa E, et al Foodborne disease outbreaks in Australia,1995 to 2000. Commun Dis Intell Q Rep. 2004;28(2):211-24.

15. Braden CR. Salmonella enterica serotype Enteritidis and eggs: a national epidemic in the United States. Clin Infect Dis. 2006;43(4):512-7.

16. Knudsen GM, Sommer HM, Sorensen ND, Olsen JE, Aabo S. Survival of Salmonella on cuts of beef carcasses subjected to dry aging. JAppl Microbiol. 2011;111(4):848-54.

17. Fey PD, Safranek TJ, Rupp ME, Dunne EF, Ribot E, Iwen PC, et al Ceftriaxone-resistant salmonella infection acquired by a child from cattle. N Engl J Med. 2000;342(17):1242-9.

18. Soltan Dallal MM, Taremi M, Gachkar L, Modarressi S, Sanaei M Bakhtiari R, et al. Characterization of antibiotic resistant patterns of Salmonella serotypes isolated from beef and chicken samples in Tehran.Jundishapur J Microbiol. 2009;2(4): 124-131.

19. Chiu LH, Chiu CH, Horn YM, Chiou CS, Lee CY, Yeh CM, et al. Characterization of 13 multi-drug resistant Salmonella serovars from different broiler chickens associated with those of human isolates. BMC Microbiol. 2010;10:86

20. International Organization for Standardization. Geneva; ISO. 1998.

21. Kauffmann F. On the classification and nomenclature of the genus Salmonella. Acta Pathol Microbiol Scand B Microbiol Immunol. 1971;79(3):421-2.

22. Shipp CR, Rowe B. A mechanised microtechnique for salmonella serotyping. JClin Pathol.1980;33(6):595.

23. Bean NH, Goulding JS, Lao C, Angulo FJ. Surveillance for foodborne-disease outbreaks--United States, 1988-1992. MMWR CDC Surveill Summ. 1996;45(5):1-66.

24. Molla B, Alemayehu D, Salah W. Sources and distribution of Salmonella serotypes isolated from food animals, slaughterhouse personnel and retail meat products in Ethiopia: 1997-2002. Ethiop J Health Dev. 2003;17(1):63-70.

25. Carraminana JJ, Rota C, Agustin I, Herrera A. High prevalence of multiple resistance to antibiotics in Salmonella serovars isolated from a poultry slaughterhouse in Spain. Vet Microbiol. 2004;104(1-2):133-9.

26. Mehrabian S, Jaberi E. Isolasion, identification and antimicrobial resistance patterns of Salmonella from meat products in Tehran. Pak J Biol Sci. 2007;10(1):122-6.

27. Acha PN, Szyfree B. Zoonoses and communicable diseases common to man and animals.Washington DC: Pan American Health Organization; 2001.

28. Redmond EC, Griffith CJ. Consumer food handling in the home: a review of food safety studies. J Food Prot. 2003;66(1):130-61.

29. Kimura AC, Palumbo MS, Meyers H, Abbott S, Rodriguez R, Werner SB. A multi-state outbreak of Salmonella serotype Thompson infection from commercially distributed bread contaminated by an ill food handler. Epidemiol Infect. 2005;133(5):823-8.

30. Aarestrup FM. Association between the consumption of antimicrobial agents in animal husbandry and the occurrence of resistant bacteria among food animals. Int J Antimicrob Agents. 1999;12(4):279-85.

31. Ansari U, Saba N, Sammad A, Qazilbash AA. Identification, characterization and antibiotic susceptibility of Salmonella and Shigella species isolated from blood and stool sample of patients in Islamabad. J Pak Med Assoc. 2002;56(1):13-6.

32. Roy P, Dhillon AS, Lauerman LH, Schaberg DM, Bandli D, Johnson S. Results of salmonella isolation from poultry products, poultry, poultry environment, and other characteristics. Avian Dis. 2002;46(1):17-24.

33. Nygard K, Lassen J, Vold L, Andersson Y, Fisher I, Lofdahl S, et al Outbreak of Salmonella Thompson infections linked to imported rucola lettuce. Foodborne Pathog Dis. 2008;5(2):165-73.

34. Nurwantoro VP, Bintoro A. M. , Legowo L. D. , Ambara A. , Prakoso S. , Purnomoadi A. Microbiological and physiological properties of beef marinated with garlic juice. J Indonesian Trop Anim Agric 2001;36(3):166-70. 